\title{
Tumor necrosis factor- $\alpha$ serum levels in healthy smokers and nonsmokers
}

This article was published in the following Dove Press journal: International Journal of Chronic Obstructive Pulmonary Disease 6 July 2010

Number of times this article has been viewed

\author{
Florin Petrescu' \\ Sebastian Cosmin Voican' \\ Isabela Silosi² \\ 'Department of Internal Medicine, \\ University of Medicine and Pharmacy \\ of Craiova, Craiova, Romania; \\ ${ }^{2}$ Department of Immunology, \\ University of Medicine and Pharmacy \\ of Craiova, Craiova, Romania
}

Background: Tobacco smoking is the most important risk factor for chronic obstructive pulmonary disease (COPD) development. Inhaled cigarette smoke can induce tumor necrosis factor- $\alpha$ (TNF- $\alpha$ ) production by alveolar macrophages, which in turn may enhance the production of metalloproteinases (MMPs). MMPs have been involved in mediating airway inflammation and lung destruction.

Objectives: We aimed to measure the TNF- $\alpha$ serum levels in healthy heavy smokers and healthy nonsmokers to determine the dose-response relationship based on the cigarette smoke exposure.

Subjects and methods: We included in our study 43 healthy heavy smokers and 19 healthy nonsmokers (the control group). The smokers group was classified as less than one pack, one pack, and more than one pack per day. A clinical and paraclinical evaluation was performed in both groups, without any evidence of infection or COPD. The serum levels of TNF- $\alpha$ were assessed by ELISA.

Results: The TNF- $\alpha$ serum levels were significantly higher for the group of smokers compared to the group of nonsmokers $(P<0.004)$. We also noticed an increased TNF- $\alpha$ concentration in the serum of smokers with more than one pack per day compared with those with less than one pack per day $(P<0.03)$. There was a positive correlation between the serum level of TNF- $\alpha$ and tobacco smoke exposure.

Conclusions: The high levels of TNF- $\alpha$ in the serum of smokers suggest an imbalance between the proinflammatory and anti-inflammatory factors as a result of tobacco smoke exposure. The concentration of TNF- $\alpha$ is elevated in the serum of healthy heavy smokers in a cigarette dosedependent manner. We speculate that the serum level of TNF- $\alpha$ might be a useful biomarker for the selection of heavy smokers with a high risk of developing smoke induced pulmonary diseases.

Keywords: tobacco smoking, inflammation, chronic obstructive pulmonary disease, metalloproteinases

\section{Introduction}

Chronic obstructive pulmonary disease (COPD) is characterized by an airflow limitation that is not completely reversible. It is a heterogeneous disease involving both airways and pulmonary parenchyma. An abnormal inflammatory response of the lung to different noxious compounds (tobacco smoke, occupational and environmental noxious substances) can also be observed. COPD is an important public health issue, the World Health Organization (WHO) estimating around 210 million cases worldwide in 2007. It is expected to become the third leading cause of death by $2030{ }^{1}$
Department of Internal Medicine, University of Medicine and Pharmacy of Craiova, Str. Petru Rares nr. 2,

Craiova 200349, Romania

Tel +40744699307

Fax +4025 I 502232

Email cosmin_voican@yahoo.com 
Although extensively studied, the underlying mechanisms of COPD development are not fully understood. The wide variety of inflammatory cells and mediators that have been found at increased levels in COPD patients ${ }^{2,3}$ suggests the major role of the inflammatory process triggered by various noxious agents, like tobacco smoke. In most world regions, tobacco smoke is by far the most communally encountered risk factor for COPD. However, although not all heavy smokers develop the disease, the absolute risk exceeds $25 \%{ }^{4}$ This individual variability suggests the intervention of different genetic, epigenetic, and environmental factors that act synergistically to determine the overall risk of COPD. Alpha1-antitrypsin deficiency is the best documented genetic risk factor for COPD development, but it accounts for only $1 \%-2 \%$ of all cases. ${ }^{5}$ Tumor necrosis factor- $\alpha$ (TNF- $\alpha$ ) gene polymorphism is another genetic factor that might determine the susceptibility to COPD. ${ }^{6}$ The above data are also supported by the observation that TNF-308A allele has been associated with an increased transcriptional activity in various diseases. ${ }^{7,8}$ TNF- $\alpha$ was originally described as a factor produced by the endotoxin stimulated macrophages that causes hemorrhagic necrosis of tumors. ${ }^{9}$ It is a powerful proinflammatory cytokine with pleiotropic properties and a key mediator of inflammation. TNF- $\alpha$ operates by binding to two structurally related cell surface receptors: p55 and p75. However, the p55 receptor seems to be responsible for mediating the majority of TNF- $\alpha$ function. ${ }^{10,11}$ Both receptors can be proteoliticaly cleaved and released as soluble forms, a good marker of TNF- $\alpha$ activation. TNF- $\alpha$ is one of the most extensively studied cytokines in COPD. An increased level of TNF- $\alpha$ has been found in induced sputum or lung biopsy of COPD patients. ${ }^{12-14}$ In a rat model of COPD, high levels of TNF- $\alpha$ have also been observed in the bronchoalveolar lavage fluid and serum, suggesting the important role of this cytokine in the initiation and progression of the inflammatory process of the lung. ${ }^{15}$ Although TNF- $\alpha$ inhibitors had no clinically beneficial effects in COPD patients, ${ }^{16}$ a recent study demonstrated a significant reduction of the smoke-induced alveolar septal tissue destruction in rats. ${ }^{17}$

Various studies suggest that TNF- $\alpha$ and its receptors could be useful biomarkers with a potential prognostic value in several diseases associated with local and systemic inflammation. Moreover, a recent study also found a significant increase in the serum p75 receptor levels in patients with peripheral arterial disease. ${ }^{18}$ Important evidence also suggests that cigarette smokers are at higher risk of inflammatory cardiovascular disease when compared to nonsmokers. ${ }^{19}$ Tappia et al showed that TNF- $\alpha$ production in the blood from smokers exposed to endotoxin was 38\% higher than in nonsmokers..$^{20}$ It is now accepted that COPD is a preventable condition, and only a protportion of heavy smokers develop the disease. Therefore, there is a need to identify new biomarkers which could assess the individual risk of the disease in order to increase the efficacy of primary and secondary prevention. Considering the above evidence, we hypothesize that TNF- $\alpha$ might be a useful biomarker to assess airways' inflammation and the risk of developing COPD in heavy smokers. In this study we aimed to assess the serum levels of TNF- $\alpha$ in healthy heavy smokers and nonsmokers, and to find a correlation between TNF- $\alpha$ serum level and quantity of smoking.

\section{Subjects and methods Subjects}

We designed an observational, prospective, cohort study: 43 healthy smokers and 19 healthy nonsmokers were randomly included. All were of Caucasian origin. We enrolled smokers that had registered for a smoking cessation program for the first time. The control group comprised healthy hospital workers who had never smoked. As the study group was not sufficiently large to eliminate the sex differences, all subjects were male. Informed consent was obtained from each subject before inclusion (a comprehensive description of the study was previously provided). The study was approved by the Ethical Committee of the University of Medicine and Pharmacy of Craiova, Romania.

A detailed medical history, physical examination, and blood tests were performed. Both smokers and nonsmokers had no evidence of any significant disease (including chronic bronchitis). In order to minimize the influence of other factors, each subject had to fulfill the following inclusion criteria: 1 . absence of any systemic disease, including autoimmune diseases; 2 . absence of any infection during the previous two months; 3 . body mass index (weight in $\mathrm{kg}$ divided by the square of height in $\mathrm{m}$ ) $<25 \mathrm{~kg} / \mathrm{m}^{2}$; 4 . no history of chronic alcohol abuse; 5 . absence of any drug intake during the previous 3 months (including medication for acute medical conditions, as the common cold). We used two additional inclusion criteria for the smoker group: 1. smoking history of at least 20 pack-year, and 2. smoking habit of at least 10 cigarettes per day. Former smokers were excluded. Nonsmokers were defined as zero cigarettes lifelong. A total number of 62 participants were approached initially, but 19 participants were excluded for different reasons: presence of comorbidities (hypertension in five subjects; chronic viral hepatitis in two subjects; psoriasis in one subject; chronic 
renal failure in 1 subject), drug intake during the previous 3 months (four subjects), overweight (two subjects), alcohol abuse (two subjects), light smoking history (two subjects).

\section{Pulmonary function tests}

Forced expiratory volume in one second $\left(\mathrm{FEV}_{1}\right)$ and forced vital capacity (FVC) were measured with standard spirometric techniques. Both smokers and nonsmokers had normal spirometric parameters.

\section{Methods}

The venous blood samples were drawn in the morning between 7:30 and 8:00 AM, after an overnight fast and before the first morning cigarette. They were immediately centrifuged at $1500 \mathrm{rpm}$ for 10 minutes; the plasma was stored at $-20^{\circ} \mathrm{C}$ until analyzed. The serum levels of TNF- $\alpha$ were performed with a commercially available ELISA kit, following the instructions provided by the manufacturer (DRG Diagnostics, Germany).

\section{Statistical analysis}

Data are expressed as mean \pm standard deviation (SD). The comparison of variables between our groups of subjects was performed using the Student's $t$-test. A $P$ value below 0.05 was considered statistically significant. The Pearson's correlation technique was used to evaluate the associations between variables.

\section{Results}

The characteristics of the study groups are shown in the Table 1 . The average age of our subjects was not significantly different between the groups. The smoker group had a significantly higher serum level of C-reactive protein (CRP).

The serum levels of TNF- $\alpha$ were significantly higher in the smoker group than in the nonsmoker group $(P<0.004$; Figure 1). We then divided our smoker group into smokers of less than 1 pack/day (16 subjects) and smokers of more

Table I The characteristics of our smokers and nonsmokers group

\begin{tabular}{llll}
\hline & Smokers & Nonsmokers & $P$ value \\
\hline Age (years) & $52.06 \pm 5.86$ & $55.21 \pm 8.5$ & NS \\
Male sex (\%) & 100 & 100 & NS \\
Pack-year & $30.16 \pm 10.02$ & - & - \\
Pack/day & $1.07 \pm 0.37$ & - & - \\
BMl $\left(K g / \mathrm{m}^{2}\right)$ & $22.01 \pm 1.64$ & $21.78 \pm 1.84$ & NS \\
Alcohol consumption & $27.53 \pm 10.92$ & $24 \pm 11.73$ & NS \\
(g/day) & & & \\
CRP $(\mathrm{mg} / \mathrm{L})$ & $12.81 \pm 9.72$ & $8.42 \pm 5.87$ & $<0.05$ \\
\hline
\end{tabular}

Note: Mean \pm SD.

Abbreviations: NS, not significant; BMI, body mass index; CRP, C-reactive protein.

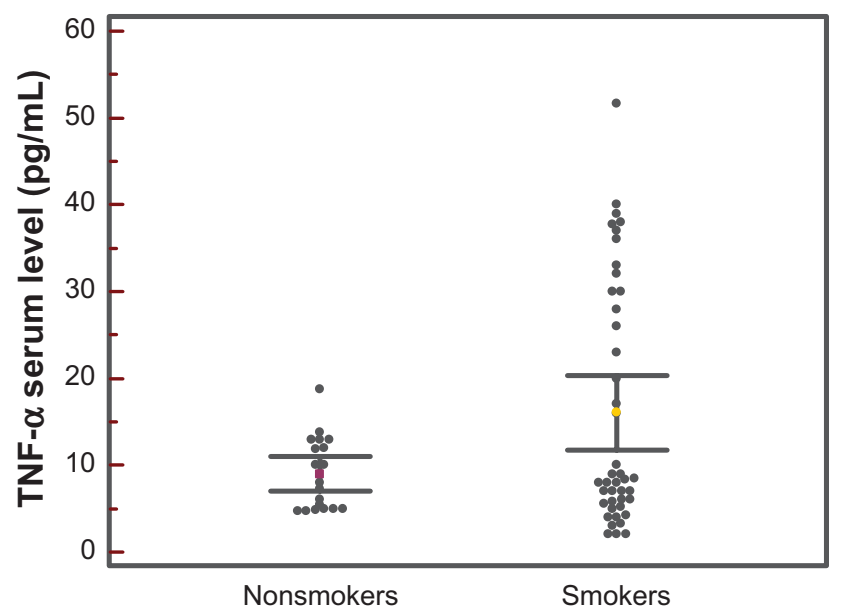

Figure I The tumor necrosis factor- $\alpha$ (TNF- $\alpha)$ serum levels in smokers and nonsmokers $(P<0.004)$.

than 1 pack/day (18 subjects). We found a significantly higher serum level of TNF- $\alpha$ in subjects that smoked more than 1 pack/day $(P<0.03$; Figure 2$)$. When we further compared the concentration of TNF- $\alpha$ in the serum of nonsmokers and smokers with a daily exposure of less than 1 pack, the between-group difference did not reach statistical significance $(P=0.17$; Figure 3$)$.

There was a positive correlation between the levels of TNF- $\alpha$ in the serum of our smoker subjects and the total smoking exposure (quantified as pack-year), the daily smoking exposure (quantified as pack/day) and the CRP serum levels $(\mathrm{r}=0.591, \mathrm{r}=0.395$, and $\mathrm{r}=0.506$, respectively; Figure 4).

\section{Discussion}

The main finding of our study was the high serum level of TNF- $\alpha$ in healthy heavy smokers compared to nonsmokers.

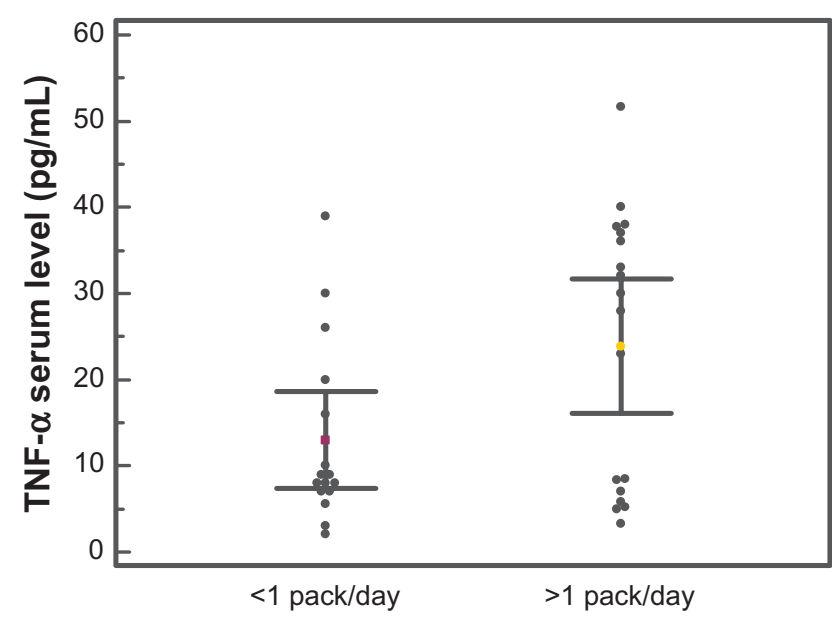

Figure 2 Tumor necrosis factor- $\alpha$ (TNF- $\alpha$ ) serum levels in smokers, according to their daily smoking exposure $(P<0.03)$. 


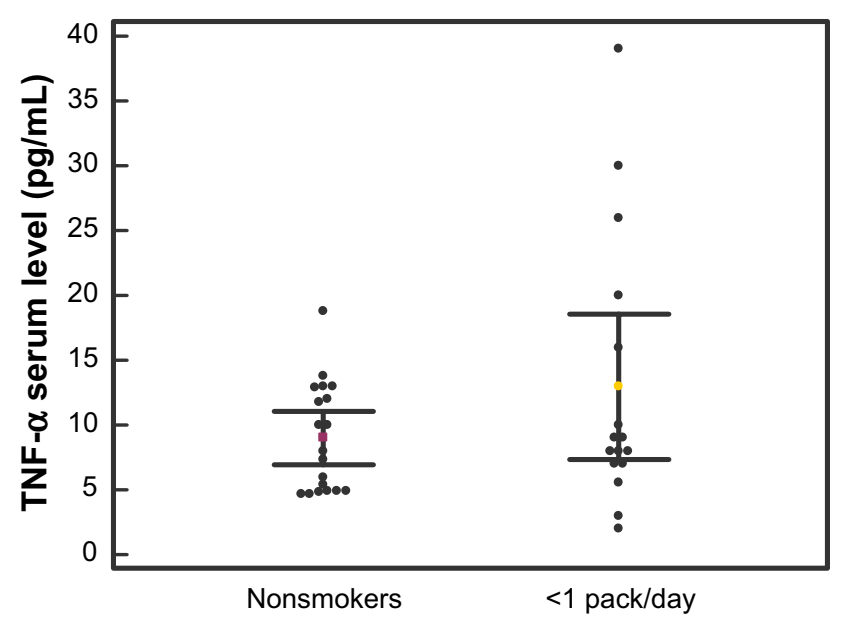

Figure 3 Tumor necrosis factor- $\alpha$ (TNF- $\alpha$ ) serum levels in nonsmokers and smokers with less than I pack/day smoking exposure $(P<0.17)$.

To the best of our knowledge, this is the first study that demonstrates a clear difference in TNF- $\alpha$ serum levels between smokers and nonsmokers. Zoppini and coworkers $^{21}$ reported that type 1 diabetic smokers had increased serum levels of the p55 receptor compared to healthy nonsmokers or diabetic nonsmokers. Another study conducted by Fernandez-Real et a ${ }^{22}$ showed that circulating levels of p75 receptors were significantly higher in healthy smokers than in nonsmokers, despite the lower fat mass in the smoker group. Both soluble TNF- $\alpha$ receptors (sTNFRs), $\mathrm{p} 55$ and $\mathrm{p} 75$, are increased in the serum of patients with different inflammatory diseases. ${ }^{23}$ TNF- $\alpha$ degradation is significantly delayed in the presence of its soluble receptors which suggests that sTNFRs could be a more sensitive marker of activation of the TNF- $\alpha$ system. ${ }^{24}$ Our findings are also supported by the observations of Boström et $\mathrm{al}^{25}$ who reported an increased level of TNF- $\alpha$ in the gingival crevicular fluid of smoker patients compared to nonsmoker patients with periodontal disease. In contrast to our results, Kuschner and coworkers ${ }^{26}$ showed that TNF- $\alpha$ levels were not significantly different between healthy smokers and nonsmokers in bronchoalveolar lavage fluid. However, both research group size and smoking exposure were smaller in their study, aspects that might explain the contrasting results. A recent study conducted by Diez-Pina et $\mathrm{a}^{27}$ reported that male smokers had higher TNF- $\alpha$ levels than male nonsmokers in the exhaled breath condensate, which may signal the presence of a smokeinduced inflammatory process in the lungs of healthy subjects. The smoke-induced inflammatory response could also vary depending upon gender or ethnicity. Some studies have already shown that tobacco smoke effects might be sex- and race-dependent. ${ }^{28,29}$ We were not able to verify
A

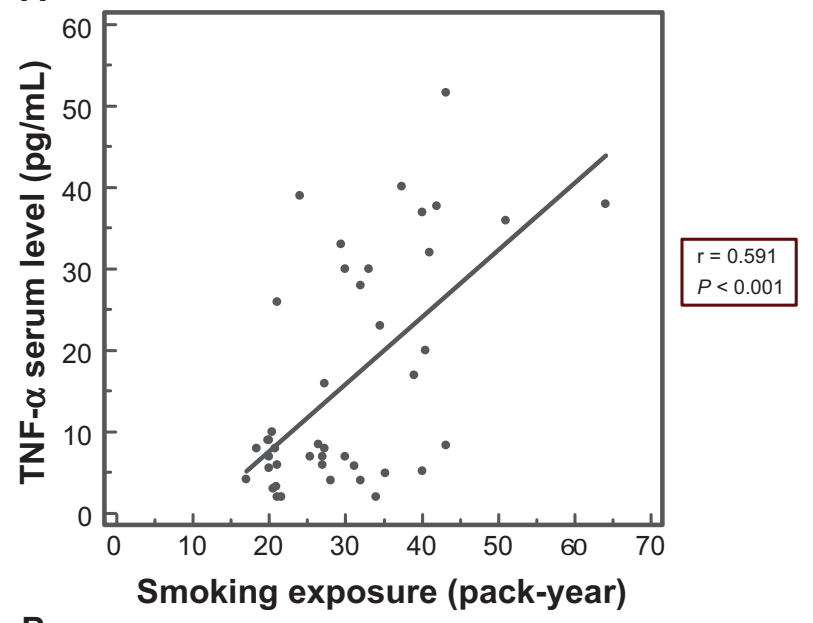

B
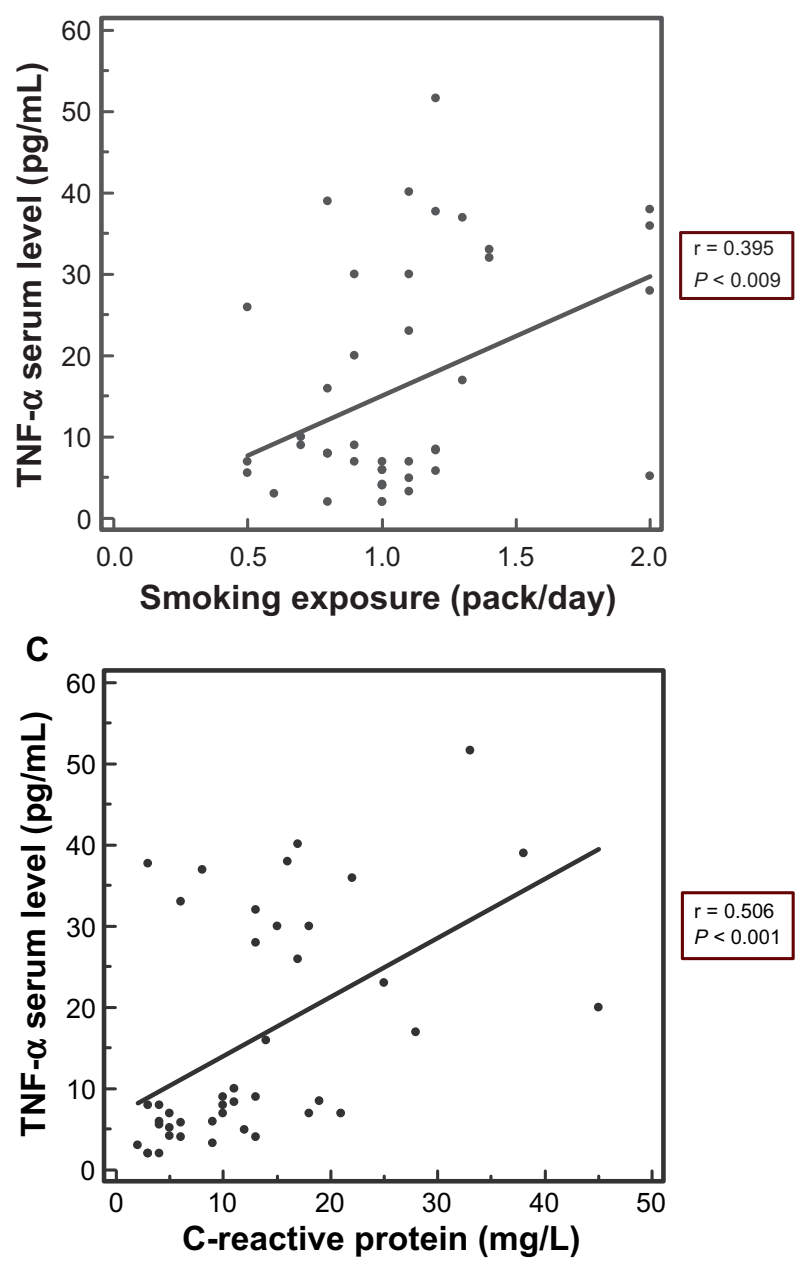

Figure 4 The serum levels of tumor necrosis factor- $\alpha$ (TNF- $\alpha$ ) and total smoking exposure were positively correlated (A). A positive correlation could also be seen between the TNF- $\alpha$ serum levels, the daily smoking exposure and the $\mathrm{C}$-reactive protein (CRP) serum levels $(\mathbf{B}, \mathbf{C})$.

the influence of these two factors on the serum levels of TNF- $\alpha$ due to the small size of our study group.

The major role of TNF- $\alpha$ in smoke-induced lung injuries is supported by a large number of studies. It was reported 
that TNF- $\alpha$ overexpression induced histological features of both emphysema and pulmonary fibrosis in transgenic mice. ${ }^{30}$ A recent study conducted by D'hulst and coworkers ${ }^{31}$ demonstrated that $\mathrm{p} 75$ receptor knockout mice were protected against cigarette smoke induced pulmonary emphysema. The authors also showed that cigarette smoke exposure increased the inflammatory infiltrate in the bronchoalveolar lavage fluid of wild type, p55 knockout or p75 knockout mice, in comparison with air-exposed mice. However, both p55 and p75 knockout mice showed weaker lung inflammation, suggesting the major role of TNF- $\alpha$ system in the mediation of smoke-induced lung injury. Other authors reported a significant increase in the mRNA expression of TNF- $\alpha$ in the lungs of guinea pigs following a single dose exposure to cigarette smoke. ${ }^{32}$ The components of cigarette smoke that are responsible for the local and systemic inflammatory response have not been fully elucidated. The bacterial endotoxin contained in tobacco can survive combustion as an active compound of tobacco smoke. ${ }^{33}$ Thus, it might be one of the many pathologic substances involved in cigarette smoke-induced inflammatory reaction.

We showed a further increase of TNF- $\alpha$ serum levels in patients who had a daily smoke exposure of more than 1 pack/ day. There was no significant difference between the serum levels of TNF- $\alpha$ of nonsmokers and those who smoked less than 1 pack daily. This observation might suggest that the smoke-induced activation of inflammation usually requires a significant amount of exposure. The serum levels of TNF- $\alpha$ were also positively correlated with the total smoke exposure (pack-year), the daily smoke exposure (pack/day) and the CRP serum levels. Our findings are in agreement with the observations of Zoppini et $\mathrm{al}^{21}$ who demonstrated a marked increase of TNF- $\alpha$ system activation with an increase in the number of cigarettes smoked per day. Similar results were reported by Fernandez-Real and coworkers. ${ }^{22}$

In conclusion, we found that heavy smoking could induce a significant increase in serum TNF- $\alpha$ and CRP levels, suggesting the imbalance between the proinflammatory and antiinflammatory factors. The concentration of TNF- $\alpha$ was elevated in the serum of healthy heavy smokers in a dose dependent manner. Based on our findings and the other data in the literature, we speculate that the serum levels of TNF- $\alpha$ and CRP might be useful biomarkers for the selection of heavy smokers with a high risk of developing smoke induced pulmonary diseases. Further studies are necessary to evaluate the prognostic value of these markers in a large population group. It would also be interesting to assess the correlation between the serum levels of TNF- $\alpha$ or CRP and the airways inflammation of this group of subjects. Future studies will have to focus on additional potential markers in order to develop a specific biomarker panel to assess the tobacco smoke susceptibility of healthy smokers.

\section{Disclosure}

The authors report no conflicts of interest in the present study.

\section{References}

1. World Health Organization. World Health Statistics 2008. Available from http://www.who.int/whosis/whostat/EN_WHS08_Full.pdf. Accessed March 10, 2010.

2. Barnes PJ, Shapiro SD, Pauwels RA. Chronic obstructive pulmonary disease: molecular and cellular mechanisms. Eur Respir J. 2003; 22:672-688.

3. Barnes PJ. Mediators of chronic obstructive pulmonary disease. Pharmacol Rev. 2004;56(4):515-548.

4. Løkke A, Lange P, Scharling H, Fabricius P, Vestbo J. Developing COPD: a 25 year follow up study of the general population. Thorax. 2006;61(11):935-939.

5. Silverman EK. Genetic epidemiology of COPD. Chest. 2002;121 Suppl 3:S1-S6.

6. Gingo MR, Silveira LJ, Miller YE, et al. Tumour necrosis factor gene polymorphisms are associated with COPD. Eur Respir J. 2008;31:1005-1012.

7. Braun N, Michel U, Ernst BP, et al. Gene polymorphism at position -308 of the tumor-necrosis-factor-alpha (TNF-alpha) in multiple sclerosis and its influence on the regulation of TNF-alpha production. Neurosci Lett. 1996;215:75-78.

8. Kroeger KM, Carville KS, Abraham LJ. The -308 tumor necrosis factor- $\alpha$ promoter polymorphism effects transcription. Mol Immunol. 1997;34:391-399.

9. Carswell EA, Old LJ, Kassel RL, Green S, Fiore N, Williamson B. An endotoxin-induced serum factor that causes necrosis of tumors. Proc Natl Acad Sci U SA. 1975;72:3666-3670.

10. Rothe J, Lesslauer W, Lotscher H, Lang Y, Koebel P, Kontgen F. Mice lacking the tumour necrosis factor receptor I are resistant to TNF-mediated toxicity but highly susceptible to infection by Listeria monocytogenes. Nature. 1993;364:798-802.

11. Vieira LQ, Goldschmidt M, Nashleanas M, Pfeffer K, Mak T, Scott P. Mice lacking the TNF receptor 555 fail to resolve lesions caused by infection with Leishmania major, but control parasite replication. J Immunol. 1996;157:827-835.

12. Keatings VM, Collins PD, Scott DM, Barnes PJ. Differences in interleukin- 8 and tumor necrosis factor- $\alpha$ in induced sputum from patients with chronic obstructive pulmonary disease or asthma. Am J Respir Crit Care Med. 1996;153:530-534.

13. Mueller R, Chanez P, Campbell AM, Bousquet J, Heusser C, Bullock GR. Different cytokine patterns in bronchial biopsies in asthma and chronic bronchitis. Respir Med. 1996;90:79-85.

14. Gan WQ, Man SF, Senthilselvan A, Sin DD. Association between chronic obstructive pulmonary disease and systemic inflammation: a systematic review and a meta-analysis. Thorax. 2004;59:574-580.

15. Ju CR, Xia XZ, Chen RC. Expressions of tumor necrosis factor-converting enzyme and ErbB3 in rats with chronic obstructive pulmonary disease. Chin Med J. 2007;120(17):1505-1510.

16. van der Vaart H, Koëter GH, Postma DS, Kauffman HF, Hacken NH. First study of infliximab treatment in patients with chronic obstructive pulmonary disease. Am J Respir Crit Care Med. 2005;172:465-469.

17. Zhang $\mathrm{C}$, Cai $\mathrm{S}$, Chen $\mathrm{P}$, et al. Inhibition of tumor necrosis factor- $\alpha$ reduces alveolar septal cell apoptosis in passive smoking rats. Chin Med J. 2008;121(7):597-601.

18. Murabito JM, Keyes MJ, Guo CY, et al. Cross-sectional relations of multiple inflammatory biomarkers to peripheral arterial disease: the Framingham Offspring Study. Atherosclerosis. 2009;203: 509-514. 
19. Willet WC, Green A, Stampfer MJ, et al. Relative and absolute excess risk of coronary heart disease among women who smoke cigarettes. N Engl J Med. 1987;317:1303-1307.

20. Tappia PS, Troughton KL, Langley-Evans SC, Grimble RF. Cigarette smoking influences cytokine production and antioxidant defences. Clin Sci. 1995;88:485-489.

21. Zoppini G, Faccini G, Muggeo M, Zenari L, Falezza G, Targher G. Elevated plasma levels of soluble receptors of TNF- $\alpha$ and their association with smoking and microvascular complications in young adults with type 1 diabetes. J Clin Endocrinol Metab. 2001;186:3805-3808.

22. Fernandez-Real J-M, Broch M, Vendrell J, Ricart W. Smoking, fat mass and activation of the tumor necrosis factor- $\alpha$ pathway. Int J Obes. 2003;27:1552-1556.

23. Schroder J, Stuber F, Gallati H, Schade FU, Kremer B. Pattern of soluble TNF receptors I and II in sepsis. Infection. 1995;23:143-148.

24. Aderka D, Engelmann H, MaorY, Brakebuschr C, Wallach D. Stabilization of the bioactivity of tumor necrosis factor by its soluble receptors. J Exp Med. 1992;175(2):323-329.

25. Boström L, Linder LE, Bergström J. Smoking and crevicular fluid levels of IL-6 and TNF- $\alpha$ in periodontal disease. J Clin Periodontol. 1999;26:352-357.

26. Kuschner WG, D'Alessandro A, Wong H, Blanc PD. Dose-dependent cigarette smoking-related inflammatory responses in healthy adults. Eur Respir J. 1996;9:1989-1994.
27. Diez-Pina JM, Fernandez-Aceñero MJ, Llorente-Alonso MJ, Diaz-Lobato S, Mayoralas S, Florez A. Tumor necrosis factor alpha as a marker of systemic and local inflammation in "healthy" smokers. Int J Gen Med. 2009;2:9-14.

28. Chatila WM, Wynkoop WA, Vance G, Criner GJ. Smoking patterns in African Americans and whites with advanced COPD. Chest. 2004;125:15-21.

29. Chen Y, Horne SL, Dosman JA. Increased susceptibility to lung dysfunction in female smokers. Am Rev Respir Dis. 1991;143:1224-1230.

30. Lundblad KA, Thompson-Figueroa J, Leclair T, Sullivan MJ, Poynter ME, Irvin CG. Tumor necrosis factor-alpha overexpression in lung disease: a single cause behind a complex phenotype. Am J Respir Crit Care Med. 2005;171:1363-1370.

31. D'hulst AI, Bracke KR, Maes T, De Bleecker JL, Pauwels RA, Joos GF. Role of tumour necrosis factor- $\alpha$ receptor $\mathrm{p} 75$ in cigarette smokeinduced pulmonary inflammation and emphysema. Eur Respir J. 2006;28:102-112.

32. Kubo S, Kobayashi M, Masunaga Y, Ishii H, Hirano Y, Takahashi K. Cytokine and chemokine expression in cigarette smoke-induced lung injury in guinea pigs. Eur Respir J. 2005;26:993-1001.

33. Hasday JD, Bascom R, Costa JJ, Fitzgerald T, Dubin W. Bacterial endotoxin is an active component of cigarette smoke. Chest. 1999;115: 829-835.
International Journal of COPD

\section{Publish your work in this journal}

The International Journal of COPD is an international, peer-reviewed journal of therapeutics and pharmacology focusing on concise rapid reporting of clinical studies and reviews in COPD. Special focus is given to the pathophysiological processes underlying the disease, intervention programs, patient focused education, and self management protocols.

\section{Dovepress}

This journal is indexed on PubMed Central, MedLine and CAS. The manuscript management system is completely online and includes a very quick and fair peer-review system, which is all easy to use. Visit http://www.dovepress.com/testimonials.php to read real quotes from published authors. 